\title{
Pengaruh Budaya Organisasi terhadap Motivasi Kerja Pegawai BPSDM Provinsi Jambi
}

\author{
Sutoro \\ Widyaiswara BPSDM Prov. Jambi \\ Correspondence email: sutoropondah@gmail.com
}

\begin{abstract}
The purpose of this study was to determine the description of organizational culture and work motivation, and to determine the effect of organizational culture on employee work motivation at the Human Resources Development Agency (BPSDM) of Jambi Province. This research uses descriptive quantitative method with data collection methods using questionnaires to 75 respondents. The result is that organizational culture has a positive and significant effect on employee motivation at 20.16. The conclusion is that organizational culture influences work motivation in BPSDM Jambi Province by $20.16 \%$.
\end{abstract}

Keywords:BPSDM Prov. Jambi; organizational culture and work motivation.

\section{PENDAHULUAN}

Manajemen Sumber Daya Manusia (MSDM) merupakan salah satu cara untuk meningkatkan kualitas SDM.Hal ini dikarenakan manajemen merupakan suatu kegiatan untuk mengarahkan seseorang maupun sumbersumber lainnya untuk mencapai tujuan yang telah direncanakan sebelumnya. Kualitas SDM mempunyai peranan yang sangat penting dalam mempengaruhi jalannya organisasi karena merupakan motor penggerak organisasi agar diperoleh organisasi yang efektif dan efisien.

Berbicara tentang Manajemen,secara teoritis setiap ahli memberikan pandangan yang berbeda tentang batasan manajemen, karena itu tidak mudah memberi arti universal yang dapat diterima semua orang. Namun demikian, dari pemikiran-pemikiran ahli tentang defenisi manajemen kebanyakan menyatakan bahwa manajemen merupakan suatu proses mendayagunakan orang dan sumber lainnya untuk mencapai tujuan organisasi secara efektif dan efisien.

Meskipun sebagai faktor yang sangat penting dalam sebuah organisasi, namun sumberdaya manusia tidak dapat menjalankan aktifitasnya sendiri tanpa didukung oleh faktor faktor lain. Hal tersebut karena sumberdaya manusia mempunyai keterbatasan dalam menjalankan fungsinya dalam menajemen.

Pegawai sebagai aset yang sangat penting dalam perjalanan sebuah organisasi karena memiliki bakat atau kemampuan, tenaga dan kreativitas yang sangat dibutuhkan oleh organisasi, maka setiap pegawai harus senantiasa memahami dan menghayati tugas pokok dan fungsinya sebagai sub sistem yang akan mempengaruhi sebuah sistem yang lebih besar yakni organisasi.

Pergeseran paradigma pembangunan yang semula berorientasi pada kekuatan Sumber Daya Alam (Natural Resource Based) kini telah berubah dan bertumpu pada Sumber Daya Manusia (Human Resource Based). Hal tersebut pada jangka panjang investasi dibidang pembangunan Sumber Daya Manusia akan sangat berguna, karena akan memberi kontribusi bagi perkembangan dan kemajuan suatu organisasi.Yang dimaksud dengan Organisasi adalah pengaturan yang disengaja terhadap sejumlah orang untuk mencapai tujuan tertulis Robbins dkk (2003; 16).

Budaya organisasi adalah bentuk keyakinan, nilai, cara yang bisa dipelajari untuk mengatasi hidup dalam organisasi. Budaya organisasi itu cenderung untuk diwujudkan oleh anggota organisasi, sehingga orang yang hidup dalam lingkungan tersebut merasa bisa hidup menjadi lebih baik. Sedangkan motivasi adalah pekerjaan yang dilakukan oleh manajer dalam menberikan inspirasi, semangat, dan dorongan kepada orang lain, untuk mengambil tindakan-tindakan tertentu (Lian Gie dalam Samsudin, 2006; 281-282).

Berdasarkan Peraturan Gubernur Nomor 59 Tahun 2016 berisi tentang kedudukan, susunan organisasi, tugas dan fungsi, serta tata kerja Badan Pengembangan Sumber Daya Manusia Provinsi Jambi, merupakan salah satu komitmen pemerintah, serta sebagai strategi organisasi dalam rangka meningkatkan sumber daya aparatur pemerintah daerah. Sebelum adanya peraturan tersebut organisasi ini adalah sebuah Badan Pendidikan dan Pelatihan Daerah Provinsi Jambi, yang tugasnya menyelenggarakan pendidikan dan pelatihan aparatur dilingkungan pemerintah provinsi Jambi.

Badan Pengembangan Sumber Daya Manusia Provinsi Jambi, dalam menjalankan tugas pokok dan fungsinya bertujuan untuk mencapai visi, yaitu mewujudkan aparatur sipil negara yang memiliki kompetensi, dedikasi, dan integritas. Memiliki kompetensi artinya karakteristik dan kemampuan kerja yang mencakup aspek pengetahuan, keterampilan, dan sikap sesuai tugas dan fungsi jabatan. Dedikasi artinya pencurahan tenaga, pikiran, dan waktu demi keberhasilan tujuan organisasi sebagai wujud daari pengabdian. Integritas artinya ketaatan kemampuan bertindak secara konsisten untuk merasa memiliki sesuai dengan nilai-nilai hukum, sosial dan agama. Untuk 
mewujudkan visi tersebut, Badan Pengembangan Sumber Daya Manusia Provinsi Jambi menetapkan misi sebagai berikut: 1) menyelenggarakan pengembangan sumber daya manusia aparatur berbasis kompetensi yang berdaya guna berhasil guna;2) mewujudkan kelembagaan pengembangan sumber daya manusia aparatur yang memadai, efektif, efisien dan akuntabel.

Sebagai lembaga teknis daerah, Badan Pengembangan Sumber Daya Manusia Provinsi Jambi memiliki fungsi dan peran strategis. Pertama, lembaga teknis merupakan sebuah support system satuan kerja pemerintah daerah secara secara keseluruhan. Bentuk dukungan tersebut adalah mendidik dan melatih aparatur pemerintah provinsi Jambi agar dapat menjadi sumber daya utama dalam proses-proses pembangunan provinsi Jambi. Kedua, Badan Pengembangan Sumber Daya Manusia Provinsi Jambi memiliki tugas yang terkait dengan peningkatan kompetensi sumber daya manusia aparatur, yang merupakan sumber daya utama dalam menggerakkan program dan kegiatan yang telah dicanangkan. Pelaksanaan Program dan kegiatan tersebut adalah menyelenggarakan pengembangan kompetensi dilingkungan pemerintah Provinsi dan Kabupaten/Kota, dan menyelenggarakan sertifikasi kompetensi di lingkungan pemerintah Provinsi/Kabupaten/ Kota. Ketersediaan sumber daya aparatur yang profesional mutlak dibutuhkan dalam rangka mewujudkan visi dan misi organisasi atau visi dan misi pemerintah daerah.

Selanjutnya, dalam menjalankan roda organisasinya BPSDM menerapkan budaya organisasi dengan nilai-nilai: profesional, berintegritas, bertanggung jawab, kerjasama, dan disiplin.

Sebagai suatu organisasi atau SKPDBadan Pengembangan Sumber Daya Manusia Provinsi Jambi memiliki beban kerja yang harus dipikul oleh organisasi tersebut. Berhasil tidaknya beban tersebut dikerjakan oleh organisasi tergantung dari kinerja pegawai yang ada didalam SKPD tersebut.

Ada beberapa faktor yang mempengaruhi keberhasilan pegawai dalam menjalankan tugas, faktor tersebut diantaranya adalah kemampuan pegawai dalam menjalankan tugasnya, kondisi budaya lingkungan organisasi, kepemimpinan dari top manajer dan lain- lain yang dapat memberikan rangsangan motivasi kepada pegawainya untuk berkinerja dengan baik.

Organisasi pemerintah merupakan instansi pelayanan publik yang memberikan pelayanan yang efektif dan efisien kepada masyarakat.Latar belakang pendidikan pegawai, faktor iklim budaya sebuah organisasi juga berpengaruh terhadap kelangsungan sebuahorganisasi. Karena budaya yangsudah tertanam dalam organisasi sangat sulit untuk diubah. Budaya organisasi yang baik akan menyebabkan pegawai berkinerja baik, tapi sebaliknya budaya organisasi yang tidak baik meskipun yang bersangkutan mempunyai kemampuan kerja yang tinggi maka kualitas produk yang dihasilkan juga akan tidak baik, hal tersebut disebabkan oleh menurunkan kinerja pegawai.

Adanya acara tertentu dalam setiap kegiatan baik kegiatan kedinasan maupun acara keagamaan menjadikan acara seremonial tersebut menjadi sebuah budaya dari SKPD. Dikatakan budaya karena hal tersebut dilakukan secara terus menerus dan dalam setiap kegiatan dan diwariskan secara turun temurun dari pemimpin yang satu ke pemimpin penggantinya.

Kepemimpinan mempunyai pengaruh yang sangat besar terhadap jalannya organisasi, karena melalui kepemimpinan akan dapat menciptakan budaya organisasi. Budaya Organisasi yang nyaman akan memotivasi karyawan untuk berkinerja sehingga produktivitas yang dicapai pegawai akan tinggi. Sebaliknya budaya organisasi yang tidak nyaman akan menyebabkan karyawan tidak termotivasi bekerja sehingga produktivitasnya rendah. Sumber Daya Manusia (SDM) dalam bekerja pada suatu kegiatan juga dapat dipengaruhi oleh semangat kerja dan motivasi (Robbins, 2006; 105).

Selanjutnya, pegawai yang tidak termotivasimemiliki rasa tidak bergairah dalam bekerja, sehingga pekerjaan yang dilakukan tidaklah maksimal dan memiliki dampak produktivitas yang tidak sesuai dengan keinginan. Wujud pegawai yang tidak termotivasi dalam bekerja disebabkan oleh kepemimpinan atau budaya organisasi disinyalir ada yang mengajukan pindah dari SKPD yang satu ke SKPD yang lain.Jika hal tersebut tidak bisa dilakukan, makayang bersangkutan akan melaksanakan pekerjaanya hanya sekedar melakukan kerja atau bahkan kehadirannyapun hanya sekedar mengisi daftar hadir.

Jika seorang karyawan/ pegawai tidak mempunyai kecakapan sesuai yang dipersyaratkan, budaya yang tidak kondusif serta pimpinan yang tidak bisa memposisikan diri bukan tidak mungkin sebuah organisasi akan mengalami adanya penurunan motivasi oleh pegawai untuk berkinerja dengan baik.

Kebiasaan atau budaya yang hampir selalu dilakukan oleh pegawai pada BPSDM Provinsi Jambi adalah adanya peringatan hari-hari keagamaan dalam rangka memberikan siraman rohani kepada karyawannya, sehingga dalam bekerja para pegawai senantiasa termotivasi untuk selalu bekerja keras dan ikhlas, karena dengan faktor inilah maka pegawai bisa bekerja dengan baik walaupun mungkin imbalan yang diberikan belumlah memadai. Kebiasaan lainnya adalah dalam rangka menjalin kekeluargaan dan silaturahmi antar pegawai dengan istri pegawai maka dilakukanlah arisan darma wanita yang dilakukan tiap bulannya.

\section{Literatur Review}

\section{Budaya Organisasi}

Budaya, berasal dari bahasa sansekerta yakni "budhayah" yang merupakan bentuk jamak dari kata dasar "budhi" yang berarti akal atau segala sesuatu yang 
berkaitan dengan akal pikiran, nilai - nilai dan sikap mental (Keputusan Menpan No. 25/ KEP/ M.PAN/ 04/2002).

Manusia adalah makhluk yang berbudaya, setiap aktifitasnya mencerminkan sistem kebudayaan yang berintegrasi dengan dirinya, baik cara berpikir, memandang sebuah permasalahan. Pengambilan keputusan dan lain sebagainya. Kata budaya (Culture) berasal dari kata majemuk budidaya yang berarti "daya dari budi" atau "daya dari akal" yang berupa cipta, karsa dan rasa (Maran, 2007:24).

Dalam beberapa literatur istilah budaya perusahaan atau corporate culture sering diganti dengan budaya organisasi atau organization culture. Menurut Sunyoto (2013: 225) Kedua istilah tersebut dianggap memiliki pengertian yang sama, Selanjutnya Robbins dan Judge dalam Sunyoto (2013:225) mendefinisikan budaya organisasi sebagai sebuah sistem makna bersama yang dianut oleh para anggota organisasi yang membedakan organisasi tersebut dengan organisasi yang lain. Sistem makna bersama ini merupakan sekumpulan karakteristik kunci yang dijunjung tinggi oleh organisasi.Budaya organisasi berkaitan dengan bagaimana karyawan memahami karakteristik budaya suatu organisasi, dan tidak terkait dengan apakah karyawan menyukai karakteristik itu atau tidak. Budaya organisasi adalah suatu sikap deskriptif, bukan seperti kepuasan kerja yang lebih bersifat evaluatif.

Budaya organisasi yang efektif membantu organisasi mengantisipasi dan beradaptasi dengan perubahan lingkungan. Proses pengembangan budaya organisasi yang adaptif dimulai dengan kepemimpinan. Seorang pemimpin harus dapat menciptakan dan mengimplementasikan visi dan strategi yang sesuai dengan konteks organisasi. Kemampuan adaptasi harus ditingkatkan dari waktu ke waktu dengan mengkombinasikan antara sukses organisasi dan fokus kepemimpinan yang specifik.Kemampuan pendiri dalam menciptakan budaya tidak dibatasi oleh nilai-nilai dan idiologi sebelumnya. Mereka dapat dengan mudah menerapkan keyakinan mereka pada organisasi untuk mencapai nilai-nilai yang diinginkan, namun lambat laun nilai-nilai ini akan terseleksi dengan sendirinya untuk melakukan sejumlah penyesuaian terhadap perubahan.

Fungsi budaya pada umumnya sukar dibedakan dengan fungsi budaya kelompok atau budaya organisasi, karena budaya merupakan gejala sosial. Yukl dalam Sunyoto (2013 :227) fungsi utama budaya organisasi adalah membantu memahami lingkungan dan menentukan bagaimana meresponnya, sehingga dapat mengurangi kecemasan, ketidak pastian dan kebingungan. Selanjutnya Sunyoto menjelaskan dua fungsi utama budaya organisasi yaitu sebagai integrasi internal, dimana para anggota organisasi dapat bersatu sehingga mereka akan mengerti bagaimana berinteraksi satu dengan yang lain. Fungsi integrasi internal ini akan memberikan seseorang dan rekan kerja lainnya identitas kolektif serta memberikan pedoman bagaimana seseorang dapat bekerjasama secara efektif dan sebagai proses adaptasi eksternal, dimana budaya organisasi akan menentukan bagaimana organisasi memenuhi berbagai tujuannya dan berhubungan dengan pihak luar. Fungsi ini akan memberikan tingkat adaptasi organisasi dalam merespons perubahan zaman, persaingan, inovasi, dan pelayanan terhadap konsumen.

Robbins (2002:283) fungsi budaya didalam sebuah organisasi adalah untuk menyampaikan rasa identitas kepada anggota-anggota organisasi, mempermudah penerusan komitmen hingga mencapai batasan yang lebih luas, melebihi batasan ketertarikan individu, budaya mendorong stabilitas sistem sosial, budaya merupakan suatu ikatan sosial yang membantu memikat kebersamaan organisasi dengan menyediakan standar-standar yang sesuai mengenai apa yang harus dikatakan atau dilakukan karyawan, dan budaya bertugas sebagai pembentuk rasa dan mekanisme pengendalian yang memberi panduan dan bentuk perilaku serta sikap karyawan. Sutanto dalam Matondang (2008: 60) fungsi budaya organisasi ada 2 yakni : berperan dalam pelaksanaan tugas bidang sumber daya manusia dan merupakan acuan dalam penyusunan perencanaan posisioning organisasi yang akan dikuasai.Dari beberapa pendapat para ahli tersebut pada umumnya mempunyai kesamaan yang intinya bahwa budaya organisasi sebagai perekat sosial dan alat pemersatu serta memberikan petunjuk bagaimana seharusnya anggota organisasi berperilaku.

Membangun budaya organisasi tentu tidak semudah mengucapkannya, harus melalui suatu proses lama dan berkelanjutan. Disebut berkelanjutan karena nilai-nilai dan norma-norma yang terkandung didalam budaya organisasi tersebut terus - menerus mengalami perubahan dan berkembang sesuai dengan zaman (Matondang, 2008:45).Para peneliti berusaha untuk mengidentifikasi dan mengukur budaya organisasi dengan tujuan untuk mempelajari hubungan antara tipe efektivitas budaya dan organisasi. Mereka didorong atas dorongan oleh adanya anggapan bahwa budaya tertentu lebih efektif dari budaya yang lain.

Sunyoto (2013:228) ada 3 tipe budaya organisasi yakni: budaya konstruktif;, budaya pasif-defensif, dan budaya agresif-defensif dimana masing-masing tipe berhubungan dengan seperangkat keyakinan normatif yang berbeda. Keyakinan normatif menunjukkan pemikiran dan keyakinan individu mengenai bagaimana anggota dari suatu kelompok atau organisasi diharapkan menjalankan tugasnya dan berinteraksi dengan orang lain (Kreitner dan Kinichi dalam Sunyoto 20013:228).Budaya organisasi merupakan bentuk keyakinan, nilai, cara yang bisa dipelajari untuk mengatasi dan hidup dalam organisasi. Budaya organisasi itu cenderung untuk diwujudkan oleh anggota organisasi. Pengertian diatas menekankan bahwa budaya organisasi berkaitan dengan aspek subjektif dari 
seseorang dalam memahami apa yang terjadi dalam organisasi. Hal ini dapat memberikan pengaruh dalam nilai-nilai dan norma-norma yang meliputi semua kegiatan bisnis, yang mungkin terjadi tanpa disadari. Kebudayaan dapat menjadi pengaruh yang signifikan pada perilaku seseorang.

Soejadmoko dalam Matondang (2008 : 46) mengatakan "Perusahaan yang unggul adalah perusahaan yang mempunyai keunggulan manajemen dengan kepemimpinan yang unggul akan berhasil mempertahankan keunggulannya tersebut.Faktor "berhasil mempertahankan" ini ternyata merupakan faktor "nilai"tepatnya nilai budaya. Budaya organisasi merupakan sistem yang dianut oleh seluruh anggota organisasi yang mempunyai karakteristik dimensi yang membedakan suatu organisasi tersebut dengan organisasi lainnya.

Indikator budaya organisasi menurut Sunyoto ( 2012 : 225) adalah inovasi dan keberanian mengambil resiko, perhatian pada hal-hal yang rinci (attention to detail) adalah sejauh mana manajemen berfokus lebih pada hal-hal detail, orientasi hasil (outcome orientation), adalah sejauh mana manajemen berfokus lebih pada hasil dibandingkan dengan teknik dan proses yang digunakan, orientasi pada orang (people orientation) adalah sejauh mana keputusan manajemen mempertimbangkan efek dari hasil tersebut atas orang yang ada dalam organisasi, orientasi tim (tim orientation), adalah sejauh mana kegiatan kerja diorganisir pada tim, keagresifan (Agressiveness) adalah sejauh mana orang bersikap agresif dibandingkan santai, stabilitas (stability) adalah sejauh mana kegiatan organisasi menekankan status quo dalam perbandingannya dengan pertumbuhan.

\section{Motivasi}

Motivasi adalah proses mempengaruhi atau mendorong dari luar terhadap seorang atau kelompok kerja agar mereka mau melaksanakan sesuatu yang diterapkan. Motivasi atau dorongan (driveng force) dimaksudkan sebagai desakan yang alami untuk memuaskan dan mempertahankan kehidupan.

Jeral Greenberg dan Robert A. Baron dalam Wibowo (2013:379) mengatakan motivasi merupakan serangkaian proses yang membangkitkan (arouse), mengarahkan (direct), dan menjaga (maintain) perilaku manuasia menuju pada pencapaian tujuan.

Beberapa faktor yang dapat mepengaruhi motivasi kerja antara lain atasan, kolega, sarana fisik, kebijaksanaan, peraturan, imbalan jasa uang dan nonuang, jenis pekerjaan dan tantangan. Motivasi individu dipengaruhi pula oleh kepentingan pribadi dan kebutuhannya masing-masing. Mangkunegara (2001, 68), motivasi terbentuk dari sifat (attidute) seorang pegawai mengatasi situasi (situation) kerja. Motivasi merupakan kondisi yang menggerakan diri pegawai yang terarah untuk mencapai tujuan organisasi (tujuan kerja).
Nawawi $(2001,351)$ motivasi (motivation) pada dasarnya adalah motif (motive) yang berarti dorongan, sebab, atau alasan seseorang melakukan sesuatu. Dengan demikian motivasi berarti suatu kondisi yang mendorong atau menjadikan sebab seseorang melakukan sesuatu perbuatan/kegiataan, yang berlangsungsecara sadar. Siagian $(2002,102)$ menyebutkan motivasi merupakan daya dorong bagi seseorang untuk memberikan kontribusi, yang sebesar mungkin demi keberhasilan organisasi mencapai tujuannya. Mangkunegara (2012: 61) motivasi merupakan kondisi atau energi yang menggerakkan diri karyawan yang terarah atau tertuju untuk mencapai tujuan organisasi perusahaan. Lian Gie seperti yang dikutip oleh Samsudin (2006; 281-282), motivasi adalah pekerjaan yang dilakukan oleh manajer dalam menberikan inspirasi, semangat, dan dorongan ke orang lain, dalam hal ini karyawannya untuk mengambil tindakan-tindakan tertentu. Pemberian dorongan ini bertujuan untuk menggiatkan orang-orang atau karyawan agar mereka semangat dan dapat mencapai hasil yang dikehendaki oleh orang-orang tersebut.

Dari beberapa pengertiaan tersebut diatas, dapat disimpulkan bahwa motivasi merupakan suatu daya pendorong mengakibatkan keadaan jiwa atau kondisi mental seseorang dalam menghadapi dan melaksanakan tugas atau pekerjaannya didasari pada alasan dan tujuannya masing-masing. Motivasi sangat penting untuk peningkatan kinerja bagi pegawai. Aspek mempengaruhi motivasi seseorang yaitu dorongan eksternal dan internal. Jadi motivasi kerja adalah sesuatu yang menimbulkan dorongan atau semangat kerja.

Hasibuan (2003:86), faktor-faktor yang mempengaruhi motivasi terbagi menjadi dua metode motivasi : motivasi Langsung, yaitu motivasi (materiil \&nonmaterial) yang diberikan secara langsung kepada setiap individu karyawan untuk memenuhi kebutuhan serta kepuasannya. Jadi sifatnya khusus, seperti pujian, penghargaan, tunjangan hari raya, bonus, dan bintang jasa. Motivasi Tak Langsung, yaitu motivasi yang diberikan hanya merupakan fasilitas-fasilitas yang mendukung serta menunjang gairah kerja/kelancaran tugas sehingga para karyawan betah dan bersemangat melakukan pekerjaan. Misalnya mesin yang baik, ruangan kerja yang terang, suasana kerja, penempatan yang tepat. Motivasi tak langsung besar pengaruhnya untuk merangsang semangat bekerja karyawan sehingga produktif.

Motivasi yang dibangkitkan karena mendapatkan rangsangan dari luar merupakan motivasi eksternal, berupa peraturan, kebijakan perusahaan, interaksi antara karyawan, dan lain sebagainya. Motivasi dapat pula dibangkitkan dari dalam atau sering disebut motivasi internal. Sasaran yang ingin dicapai berada dalam individu itu sendiri.

Karyawan dapat bekerja karena tertarik dan senang pada pekerjaannya, ia merasa pekerjaan yang 
dilakukan memberikan makna, kepuaan dan kebahagiaan pada dirinya. Seorang karyawan yang memiliki semangat dan kegairahan dalam bekerja relatif sudah tertarik pada pekerjaanny, karena kerja keras memberikan kepuasan kerja pada dirinya. Faktor-faktor dilingkungan karyawan seperti aturan, kebijakan,corak hubungan dengan atasan, rekan dan bawahan dapat mempengaruhi motivasi karyawan, ini berarti bahwa faktor-faktor tersebut perlu mendapat perhatian jika memang memberikan pengaruh negatif terhadap motivasi, termasuk juga pengaturan penggajian dan insentifnya. Motivasi juga dipengaruhi oleh beberapa faktor.Mangkunegara (2012:76) pemenuhan kebutuhan pegawai merupakan fundamental yang mendasari perilaku kerja. Kita tidak mungkin dapat memotivasi kerja pegawai tanpa memperhatikan apa yang dibutuhkan oleh pegawai tersebut. Dimensi motivasi pegawai adalah kebutuhan pegawai sebagai mana yang dimaksud Mangkunegara tersebut adalah sebagaimana yang dikemukakan oleh Abraham Maslow yakni hierarki kebutuhan pegawai. Dimensi motivasi tersebut adalah Kebutuhan yang bersifat fisiologis, yaitu kebutuhan seseorang seperti makan, minum, perlindungan fisik, bernafas dan sexual. Kebutuhan ini adalah kebutuhan yang paling mendasar. Dalam hubungan ini pemimpin perlu memberikan gaji yang layak pada pegawai;Jaminan keselamatan dan keamanan , adalah kebutuhan akan keselamatan dan keamanan dari berbagai ancaman kecelakaan dalam melakukan pekerjaan. Dalam hal ini pemimpin perlu memberikan tunjangan kesehatan, asuransi kecelakaan, perumahan dan dana pensiun; Kebutuhan sosial atau rasa memiliki, merupakan kebutuhan untuk diterima dalam kelompok unit kerja, berafiliasi, beriteraksi, serta rasa dicintai dan mencintai. Dalam hubungan dengan kebutuhan ini, pemimpin perlu menerima eksistensi atau keberadaan pegawai sebagai anggota kelompok kerja, melakukan interaksi kerja yang baik dan hubungan yang harmonis; Kebutuhan harga diri, yaitu kebutuhan untuk dihormati, dihargai oleh orang lain. Dalam hubungan ini pemimpin tidak boleh sewenang-wenang memperlakukan pegawai karena mereka perlu dihormati, diberi penghargaan terhadap prestasi kerjanya; Kebutuhan aktualisasi diri, yaitu kebutuhan mengembangkan diri dan potensi, mengemukakan ide-ide, memberikan penilaian, kritik dan berprestasi. Dalam hal ini pemimpin perlu memberikan kesempatan kepada pegawai bawahan agar mereka dapat mengaktualisasikan diri secara baik dan wajar di perusahaan;

Kebutuhan perorangan (Individuals Needs) merupakan tuntunan yang berupa keinginan untuk mencapai tujuan dalam memenuhi kebutuhan atau pencapaian dan keseimbangan. Tingkat kebutuhan seseorang sangat berbeda-beda satu sama lainnya tergantung pada kondisi dan status masing-masing

Untuk indikator-indikator yang dapat digunakan untuk mengukur motivasi seseorang meliputi perhatian dan dukungan pimpinan. Konsistensi penerapan kebijakan, kesejahteraan pegawai dan keluarga, pola pembinaan karir, kemauan untuk berkembang, pekerjaan yang menantang, prestasi pribadi, kemajuan karier.

Beberapa penelitian terdahulu yang menggunakan variabel budaya organisasi, dan motivasimengungkapkan bahwa budaya bahwa budaya organisasi berpengaruh positif dan signifikan terhadap motivasi kerja karyawan, semakin baik budaya organisasi maka semakin tinggi tingkat motivasi kerja yang dimiliki oleh karyawan.Selanjutnya ditemukan bahwa budaya organisasi dan motivasi kerja juga berpengaruh positif dan signifikan terhadap kinerja karyawan, dimana jika budaya organisasi semakin baikdan motivasi kerja semakin tinggi maka dapat memberikan efek pada peningkatan kinerja karyawan (Giantari, 2017). Budaya organisasi berpengaruh signifikan terhadap Motivasi Kerja (Theolina Hormati, 2013). Hasil penelitian yang dilakukan oleh Pujiastuti, dkkmenguatkan penelitian terdahulu bahwa budaya organisasi berpengaruh signifikan terhadap motivasi kerja (Pujiastuti dkk, 2018).

\section{METODE}

Penelitian ini adalah penelitian kuantitatif deskriptif dengan metode pengumpulan data menggunakan kuesioner yang disebar kepada 75 responden di BPSDM Provinsi Jambi. Sedangkan untuk mengumpulkan dan menganalisis bukti empiris (data) dilakukan pendekatan kuantitatif dengan melakukan pengujian data secara statistik, serta dilakukan secara sistematis agar dapat memahami fenomena sosial yang sedang diteliti (Sugiyono, 2005:52).

Pendekatan kuantitatif digunakan secara khusus untuk dapat menganalisa budaya organisasi terhadap motivasi pegawai, Sedangkan, pendekatan verifikatif sendiri digunakan dengan maksud untuk dapat menerapkan analisis (data) yang lebih rinci dan mendalam.

\section{HASIL DAN PEMBAHASAN}

\section{Analisis Deskriptif Variabel Budaya Organisasi (X)}

Budaya organisasi sebagai sebuah sistem makna bersama yang dianut oleh para anggota organisasi yang membedakan organisasi tersebut dengan organisasi yang lain. Sistem makna bersama ini merupakan sekumpulan karakteristik kunci yang dijunjung tinggi oleh organisasi.

Budaya organisasi berkaitan dengan bagaimana karyawan memahami karakteristik budaya suatu organisasi, dan tidak terkait dengan apakah karyawan menyukai karakteristik itu atau tidak. Budaya organisasi adalah suatu sikap deskriptif, bukan seperti kepuasan kerja yang lebih bersifat evaluatif.Sementara, hasil analisis deskriptif data variabel budaya organisasi pada pegawai Badan Pendidikan dan Pelatihan Daerah Provinsi Jambi sebagai salah satu variabel yang diukur melalui analisis deskriptif dengan menggunakan skala likert yang dilihat dari tingkat rata-rata dan tingkat 
capaian responden. berdasarkan perolehan analisis dari masing-masing item pernyataan yang dikembangkan berdasarkan masing-masing indikator yang ada, dapat dilihat pada tabel 1, sebagai berikut:

Tabel 1. Analisi Deskriptif Variabel Budaya Organisasi (X)

\begin{tabular}{|c|c|c|c|c|c|c|c|c|c|}
\hline No & Pernyataan & $\begin{array}{c}\text { STB } \\
1\end{array}$ & $\begin{array}{c}\text { TB } \\
2\end{array}$ & $\begin{array}{c}\text { CB } \\
3 \\
\end{array}$ & $\begin{array}{l}\text { B } \\
4 \\
\end{array}$ & $\begin{array}{c}\text { SB } \\
5\end{array}$ & $\mathbf{N}$ & $\begin{array}{l}\text { Skor } \\
\text { Total }\end{array}$ & Kategori \\
\hline I & Perhatian pada hal-hal rinci/ detail & & & & & & & & \\
\hline 1. & Dalam bekerja, karyawan didorong untuk bertindak cermat & 0 & 10 & 26 & 31 & 8 & 75 & 262 & Baik \\
\hline \multirow[t]{2}{*}{2.} & $\begin{array}{l}\text { Dalam menyelesaikan tugas saya selalu dituntut untuk tepat } \\
\text { waktu }\end{array}$ & 0 & 0 & 35 & 38 & 2 & 75 & 267 & Baik \\
\hline & Rata-rata & & & & & & & 264,5 & Baik \\
\hline II & Orientasi hasil & & & & & & & & \\
\hline 3. & Dalam bekerja selalu berorientasi dan fokus pada hasil & 0 & 2 & 24 & 44 & 5 & 75 & 277 & Baik \\
\hline \multirow[t]{2}{*}{4} & $\begin{array}{l}\text { Dalam bekerja saya berusaha untuk tidak menumpuk } \\
\text { pekerjaan. }\end{array}$ & 0 & 0 & 29 & 40 & 6 & 75 & 277 & Baik \\
\hline & Rata-rata & & & & & & & 277 & Baik \\
\hline III & Orientasi pegawai & & & & & & & & \\
\hline 5 & $\begin{array}{l}\text { Dalam bekerja saya selalu mengikuti ketentuan yang berlaku } \\
\text { intern di Badan Diklat }\end{array}$ & 0 & 0 & 18 & 47 & 10 & 75 & 292 & Baik \\
\hline \multirow[t]{2}{*}{6} & $\begin{array}{l}\text { Dalam bekerja saya tidak terpengaruh dengan hal-hal yang } \\
\text { sifatnya membawa saya kearah negative }\end{array}$ & 0 & 0 & 16 & 46 & 14 & 75 & 297 & Baik \\
\hline & Rata-rata & & & & & & & 294,5 & Baik \\
\hline IV & Orientasi tim & & & & & & & & \\
\hline 7 & $\begin{array}{l}\text { Dalam menjalankan tugas saya selalu menjaga kebersamaan } \\
\text { dengan sesama pegawai }\end{array}$ & 0 & 0 & 8 & 60 & 7 & 75 & 299 & Baik \\
\hline \multirow[t]{2}{*}{8} & $\begin{array}{l}\text { Dalam bekerja, semua pegawai saya anggap sebagai rekan } \\
\text { yang saling membutuhkan }\end{array}$ & 0 & 0 & 7 & 64 & 4 & 75 & 297 & Baik \\
\hline & Rata-rata & & & & & & & 298 & Baik \\
\hline $\mathbf{V}$ & Keagresifan & & & & & & & & \\
\hline 9 & Dalam bekerja saya berusaha agresif dan ingin yang terbaik & 0 & 1 & 16 & 57 & 1 & 75 & 283 & Baik \\
\hline VI & Stabilitas & & & & & & & & \\
\hline \multirow[t]{2}{*}{10} & $\begin{array}{l}\text { Dalam menjalankan tugas saya ingin membawa nama baik } \\
\text { organisasi }\end{array}$ & & 1 & 20 & 53 & 1 & 75 & 279 & Baik \\
\hline & $\begin{array}{c}\text { Total } \\
\text { Rata-rata }\end{array}$ & & & & & & & $\begin{array}{c}2830 \\
283\end{array}$ & $\begin{array}{l}\text { Baik } \\
\text { Baik }\end{array}$ \\
\hline
\end{tabular}

Sumber : Data Diolah 2019

Berdasarkan tabel di atas, dapat dikatakan bahwa budaya organisasi di Badan Pendidikan dan Pelatihan Daerah Provinsi Jambi termasuk ke dalam kategori "Baik" dengan rata-rata variabel budaya organisasi (X1) sebesar 2830 dengan rentang skala 2.550 - 3.149, hal ini menunjukkan dengan dalam melembagakan budaya kerja aparatur yang bertujuan untuk peningkatan efesiensi, disiplin, penghematan dan kesederhanaan hidup, yang semuanya diarahkan pada perwujudan pemerintahan yang baik (good govermance) dan pemerintahan yang bersih (clean govermance). Budaya kerja aparatur negara dapat diawali dalam bentuk nilainilai yang terkandung didalam institusi atau sistem kerja, sikap dan prilaku serta peradaban bangsa

\section{Analisis Deskriptif Variabel Motivasi (Y)}

Motivasi pada diri pegawai merupakan suatu keadaan psikis yang ada dalam diri seseorang yang mendorong mereka untuk berperilaku. Dimana, keadaan psikis tersebut mencakup kemauan berprestasi dengan baik, semangat dan gairah kerja, kemauan menjalankan perintah, dan kemauan bekerja sama dalam organisasi dimana mereka bekerja saat ini.

Hasil analisis deskriptif data variabel motivasi para pegawai yang ada pada Badan Pendidikan dan Pelatihan Daerah Provinsi Jambi sebagai salah satu variabel yang diukur melalui analisis deskriptif dengan menggunakan skala likert yang dilihat dari tingkat ratarata dan tingkat capaian responden. Motivasi para pegawai disini digambarkan melalui prestasi kerja yang tinggi, gaji yang tinggi, mempunyai dedikasi yang tinggi, menyenangi profesinya, bekerja karena panggilan hati nurani, dan mendapatkan penghargaan dari pimpinan. Adapun untuk melihat secara jelas hasil perolehan analisis deskriptif dari variabel motivasi ini sendiri, dapat dilihat pada tabel 2, sebagai berikut: 
Tabel 2. Analisis Deskriptif Variabel Motivasi (Y)

\begin{tabular}{|c|c|c|c|c|c|c|c|c|c|}
\hline No & Pernyataan & $\begin{array}{c}\text { STB } \\
1 \\
\end{array}$ & $\begin{array}{c}\text { TB } \\
2 \\
\end{array}$ & $\begin{array}{c}\text { CB } \\
\mathbf{3} \\
\end{array}$ & $\begin{array}{l}\text { B } \\
4\end{array}$ & $\begin{array}{c}\text { SB } \\
5\end{array}$ & $\mathbf{N}$ & $\begin{array}{l}\text { Skor } \\
\text { Total }\end{array}$ & Kategori \\
\hline $\mathbf{I}$ & Kebutuhan fisiologis & & & & & & & & \\
\hline 1. & $\begin{array}{l}\text { Dalam bekerja saya merasa nyaman jika mempunyai } \\
\text { ruang / tempat / meja kerja sendiri }\end{array}$ & 6 & 37 & 18 & 11 & 3 & 75 & 193 & Rendah \\
\hline 2. & Adanya sarana kerja bagi setiap pegawai & 0 & 0 & 15 & 46 & 14 & 75 & 299 & Tinggi \\
\hline \multirow[t]{2}{*}{3} & Adanya Fasilitas kerja setiap pegawai & 0 & 1 & 9 & 50 & 15 & 75 & 304 & \\
\hline & Rata-rata & & & & & & & 280 & Tinggi \\
\hline II & Kebutuhan keamanan & & & & & & & & \\
\hline 4. & Adanya keamanan lingkungan kerja pegawai & 0 & 0 & 23 & 44 & 8 & 75 & 285 & Tinggi \\
\hline \multirow[t]{2}{*}{5} & $\begin{array}{l}\text { Adanya dukungan pengamanan dalam pelaksanaan } \\
\text { pekerjaan }\end{array}$ & 1 & 2 & 30 & 24 & 18 & 75 & 281 & Tinggi \\
\hline & Rata-rata & & & & & & & 292,6 & Tinggi \\
\hline III & Kebutuhan social & & & & & & & & \\
\hline 6 & Adanya hubungan timbal balik antar pegawai & 0 & 0 & 6 & 54 & 15 & 75 & 309 & Tinggi \\
\hline 7 & Adanya hubungan antar sesama petugas & 0 & 2 & 4 & 58 & 11 & 75 & 303 & Tinggi \\
\hline 8 & $\begin{array}{l}\text { Adanya hubungan petugas dengan unit kerja terkait } \\
\text { Rata-rata }\end{array}$ & 0 & 0 & 8 & 51 & 16 & 75 & $\begin{array}{c}308 \\
284,3\end{array}$ & $\begin{array}{l}\text { Tinggi } \\
\text { Tinggi }\end{array}$ \\
\hline IV & Kebutuhan harga diri & & & & & & & & \\
\hline 9 & Adanya Insentif atas pekerjaan & 0 & 0 & 14 & 47 & 14 & 75 & 300 & Tinggi \\
\hline 10 & Adanya penghargaan pimpinan & 0 & 0 & 7 & 52 & 16 & 75 & 309 & Tinggi \\
\hline 11 & Adanya insentif dari instansi pihak terkait & 0 & 0 & 8 & 52 & 15 & 75 & 307 & Tinggi \\
\hline $\mathbf{V}$ & Kebutuhan aktualisasi diri & & & & & & & & \\
\hline 12 & Adanya aktualisasi identitas petugas & 0 & 0 & 10 & 57 & 8 & 75 & 298 & Tinggi \\
\hline 13 & Adanya aktualisasi profesionalitas petugas & 0 & 0 & 15 & 46 & 4 & 75 & 299 & Tinggi \\
\hline 14 & Adanya aktualisasi akuntabilitas petugas & 0 & 0 & 16 & 59 & 0 & 75 & 284 & Tinggi \\
\hline & Rata-rata & & & & & & & 298,3 & Tinggi \\
\hline & Total & & & & & & & 4079 & Tinggi \\
\hline & Rata-rata & & & & & & & 291.3 & Tinggi \\
\hline
\end{tabular}

Sumber : Data Diolah 2019

Berdasarkan tabel di atas, dapat dikatakan bahwa motivasi pegawai dalam bekerja pada Badan Pendidikan dan Pelatihan Daerah Provinsi Jambi termasuk ke dalam kategori "Tinggi" dengan rata-rata variabel motivasi (Y) sebesar 4.079 serta rentang skala $3.570-4.409$. Dengan demikian, dengan adanya prestasi kerja yang tinggi, gaji yang tinggi, mempunyai tanggung jawab yang tinggi, mempunyai dedikasi yang tinggi, menyenangi profesinya, dan mendapatkan penghargaan dari pimpinan, pada akhirnya akan mampu untuk meningkatkan kinerja pegawai pada Badan Pendidikan dan Pelatihan Daerah Provinsi Jambi.

Pengaruh budaya organisasi terhadap motivasi dapat digambarkan sebagai gambar berikut:

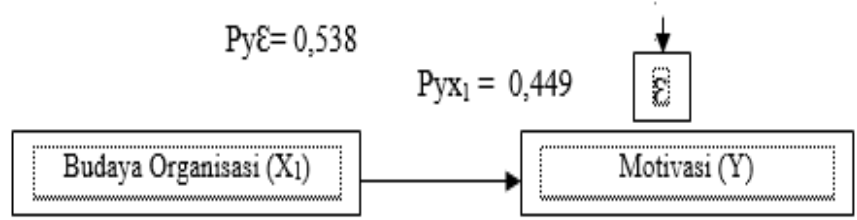

Gambar 1. Pengaruh Budaya Organisasi terhadap Motivasi

\section{Pengaruh budaya organisasi terhadap motivasi}

Besarnya pengaruh $\mathrm{X}_{1}$ terhadap $\mathrm{Y}$

$$
\begin{aligned}
\mathrm{X}_{1} \rightarrow \mathrm{Y} & =\left(\mathrm{Pyx}_{1}\right)\left(\mathrm{PyX}_{1}\right) \\
& =(0,449)(0,449) \\
& =0,2016(20,16 \%)
\end{aligned}
$$

Dari rincian diatas dapat dikatakan bahwa besarnya pengaruh budaya organisasi $\left(\mathrm{X}_{1}\right)$ terhadap motivasi (Y) sebesar 20,16. Kesimpulannya bahwa budaya organisasi mempengaruhi motivasi kerja di BPSDM Provinsi Jambi sebesar 20,16\%.

\section{Pembahasan}

Dari hasil pengujian dengan uji parsial (uji t) menyatakan bahwa Budaya Organisasi (X1) berpengaruh signifikan terhadapMotivasi Kerja pegawai BPSM

\begin{tabular}{|c|c|c|c|c|c|c|}
\hline & \multirow{2}{*}{ Model } & \multicolumn{2}{|c|}{ Unstandardized Coefficients } & Standardized Coefficients & \multirow{2}{*}{$\mathrm{t}$} & \multirow{2}{*}{ Sig. } \\
\hline & & $\mathrm{B}$ & Std. Error & Beta & & \\
\hline \multirow[t]{2}{*}{1} & (Constant) &, 545 &, 174 & & 3,132 & ,003 \\
\hline & $\mathrm{X} 1$ &, 346 &, 058 & ,449 & 6,012 & ,000 \\
\hline
\end{tabular}
Provinsi Jambi. Dapat dilihat pada tabel sebagai berikut :

Tabel 3. Uji Parsial Antara Budaya Organisasi (X1) DenganMotivasi (Y) 
Dari hasil diatas diperoleh secara parsial antara variabel Budaya Organisasi (X1) dengan variabel motivasi (Y) menunjukkan bahwa t hitung 6,012 dengan nilai Sig. 0,000.Kriteria keputusan jika Sig. penelitian < 0,05 maka $\mathrm{H} 0$ di tolak dan $\mathrm{H} 1$ di terima artinya signifikan, tetapi jika Sig. penelitian >0,05 maka H0 di terima dan $\mathrm{H} 1$ di tolak yang berarti tidak signifikan. Karena 0,000 < 0,05 maka H0 di tolak dan H1 di terima. Hasil ini menunjukkan bahwa Budaya Organisasi (X1) pegawai pada BPSDM Provinsi Jambi berpengaruh positif dan secara signifikan terhadap motivasi (Y) dan ini terbukti sehingga hipotesis di terima.

Hasil uji ini memperkuat penelitian yang disampaikan oleh Anggraeni (2012:72), dimana diungkapkan bahwa untuk lebih meningkatkan motivasi kerja pegawai dalam menyelesaikan pekerjaan harus sesuai dengan jadwal, serta pemberian penghargaan, pengembangan Budaya Organisasi, dan sanksi bagi pegawai berprestasi dan kurang berprestasi harus dilakukan.

\section{SIMPULAN}

Berdasarkan hasil penelitian dengan variabel budaya organisasi terhadap motivasi kerja pegawai yang dilakukan di BPSDM Provinsi Jambi terhadap 75 responden, maka dapat ditarik kesimpulan bahwa budaya organisasirata-ratapadakondisi/kategori "Baik" ini berarti bahwa organisasi ada keinginan melembagakan budaya kerja lebih baik. Sedangkan motivasi secara rata-rata "Tinggi" hal ini berarti bahwa prestasi kerja yang tinggi, gaji yang tinggi, tanggung jawab yang tinggi, dedikasi yang tinggi, menyenangi profesi, penghargaan dari pimpinan dapat meningkatkan kinerja.

\section{Implikasi}

Perlunya budaya kerja organisasi yang memberikan rasa aman bagi anggotanya dan pada saat yang sama atasan dapat menjadikan dirinya sebagai panutan dalam bersikap, berprilaku bermoral, profesional, disiplin, hemat, hidup sederhana, jujur, produktif, menghargai waktu, menjadi panutan dan keteladanan, serta mendapat kepercayaan dari para pegawainya.

Perlunya motivasi dari atasan kepada bawahan, mengingat motivasi dapat memberikan pengaruh menurun atau meningkatkan kinerja para pegawai secara keseluruhan, maka diperlukan adanya upaya oleh pimpinan dalam memperhatikan hal-hal apa saja yang membuat motivasi para pegawai dalam bekerja menurun, dan segera dapat mengambil tindakan yang tepat. Sehingga, pegawai merasa diperhatikan dan hal ini akan menjadi pendorong bagi terciptanya motivasi kerja yang lebih baik.

\section{DAFTAR PUSTAKA}

Ali, Hapzi, dkk. 2013. Metodologi Penelitian Petunjuk Praktis Untuk Pemecahan Masalah Bisnis, Penyusunan Skripsi, Tesis dan Desertasi. Deupublish. Yogyakarta.

Arikunto, Suharsimi. 2007. "Prosedur Penelitian Suatu Pendekatan Praktek, Edisi Revisi”. PT. Rineka Cipta. Jakarta.

Asang, Sulaiman. 2012. Membangun Sumberdaya Manusia Berkualitas, Brilian Internasional. Surabaya.

Brantas. 2009. Dasar-dasar Manajemen. Alfabeta. Bandung.

Buchari, Alma. 2009. Kewirausahaan. Alfabeta. Bandung.

Daft, Richart C. 2003. Manajemen. Edisi Kelima. Erlangga. Jakarta

Fahmi, Irham. 2011. Manajemen Kepemimpinan Teori dan Aplikasi. Alfabeta. Bandung.

Fikri, M. 2012. (Tesis)."PengaruhKepemimpinan dan Motivasi Kerja Terhadap Kinerja Pegawai Pada Dinas Pendapatan Daerah Provinsi Jambi".Magister Manajemen, FE, Universitas Batanghari Kota Jambi, (tidakdipublikasikan).

Handoko, T.H. 2002. "Manajemen Sumber Daya Manusia". BPFE UGM. Yogyakarta.

Hasan, M. Iqbal. 2005. "Pokok-pokok Materi Statistik I (statistik deskriptif) ; Edisi Kedua". Bumi Aksara. Jakarta.

Hasibuan, Malayu SP. 2003. Organisasi dan Motivasi Peningkatan Produktivitas. Bumi Aksara. Jakarta.

Ida Ayu dkk. Jurnal. Manajemen Kewirausahaan. Vol. 10 No. 2 September 2008.

Mangkunegara, Anwar Prabu. 2005. Perilaku dan Budaya Organisasi. Refika Aditama Bandung

Mangkunegara, Anwar Prabu. 2012. Perilaku dan Budaya Organisasi. Refika Aditama Bandung

Maran, Rafael Raga. 2007. Manusia \& Kebudayaan Dalam Perspektif IImu Budaya Dasar. Rineka Cipta. Jakarta.

Matondang, H.M. 2008. Kepemimpinan Budaya Organisasi dan Manajemen Strategik. Graha Ilmu. Yogjakarta.

Melahani. 2012. (Tesis). "Pengaruh Kepemimpinan, Motivasi Dan Lingkungan Kerja Terhadap Kinerja Pegawai Pada Dinas Kehutanan Provinsi Jambi”. Magister Manajemen, FE, Universitas Batanghari Kota Jambi, (tidakdipublikasikan).

Muhidin, S.A \& Maman. 2007. "Analisis Korelasi, Regresi, dan Jalur Dalam Penelitian". Pustaka Setia. Bandung.

Nawawi, Hadari. 2001. Manajemen Stratejik Organisasi Non Profit Bid Pemerintah dengan 
Ilustrasi di Bid Pendidikan. Gajah Mada Pres. Yogjakarta.

Ndraha, Talidziduhu. 1997. Budaya Organisasi. Rineka Cipta. Jakarta

Nimran Umar.2004. Perilaku Organisasi. Citra Media. Surabaya

Ranjabar, Jacobus. 2013. Sistem Sosial Budaya Indonesia, Suatu Pengantar. Alfabeta. Bandung.

Ricky W.Griffin. 2003. Manajemen. (Terjemahan) Erlangga. Jakarta.

Riduwan \& Akdon. 2009. "Rumus dan Data dalam Analisis Statistika". Alfabeta. Bandung.

Robbins, Stepphen P. 1999. Perilaku Organisasi (Terj) Hadyana Pujaatmaka Jilid 1\&2. PT Bhuana Ilmu Popular. Jakarta

Ruky, Ahmad S. 2001. Sistem Manajemen Kinerja. Gramedia Pustaka Utama. Jakarta

Samsudin, Sadili. 2006. Manajemen Sumber Daya Manusia. Cetakan ke 1. CV. Pustaka Setia Bandung.

Sedarmayanti. 2001. Sumber Daya Manusia dan Produktivitas Kerja. Mandar Maju. Bandung.

Siswanto, B. Sastrohadiwiryo. 2005. Manajemen Tenaga Kerja Indonesia Pendekatan Administratif dan Operasional Cetakan ketiga. PT Bumi Aksara. Jakarta.

Sugiyono. 2005. "Statistik Untuk Penelitian". CV. Alfabeta. Bandung.

Sunyoto, Danang. 2013. Manajemen Sumber Daya Manusia. Cetakan Kedua. Center For Academic Publising Service (CAPS). Yogjakarta.

Supardi. 2013. Aplikasi Statistika Dalam Penelitian, Konsep Statistika Yang Lebih Komprehensif. Cetakan 1, Juni 2013. Change Pulication. Jakarta. Syekh, Sayid. 2011. Pengantar Statistik Ekonomi dan Sosial. Gaung Persada Pers. Jakarta.

Umar, Husein. 2007. "Desain Penelitian MSDM dan Perilaku Karyawan : Paradigma Positivistik dan Berbasis Pemecahan Masalah". PT. Raja Grafindo Persada. Jakarta.

Winardi dkk. 2012. Pengaruh Budaya Organisasi dan Motivasi Terhadap Kinerja Karyawan Dengan Komitmen Organisasional Sebagai Variabel Intervening (Studi Pada Karyawan Dinas Pengairan Provinsi Aceh), Jurnal Ilmu Manajemen Pasca Sarjana Universitas Syiah Kuala, Volume 1. Tahun I, Mei 2012. Banda Aceh.

Yulk, Gary. 2007. Kepemimpinan Dalam Organisasi. Edisi Kelima (Terjemahan). PT Indeks. Jakarta.

Artikel nidafe.wordprees.com/2013/10/10

Jurnal Manajemen \& Kewirausahaan, Vol. 7, No. 2, September 2005: 171-188

Pujiastuti, Endah Aprilia And Umam, Moh. Rifqi Khairul. 2018.Pengaruh Budaya Organisasi Terhadap Kinerja Karyawan Dengan Variabel
Mediasi Motivasi Kerja Pada C.V. Akurat Garment, IAIN Surakarta.

Ida Ayu Indah Giantari. I. Gede Riana . 2017. Pengaruh Budaya Organisasi Terhadap Motivasi Kerja Dan Kinerja Karyawan Klumpu Bali Resort Sanur. Journal Article E-Jurnal Manajemen Universitas Udayana. 2017.

Theolina Hormat. 2013.Pengaruh Budaya Organisasi, Rotasi Pekerjaan Terhadap Motivasi Kerja Dan Kinerja Pegawai, Jurnal Emba: Jurnal Riset Ekonomi, Manajemen, Bisnis Dan Akuntansi Volume 4 No2 2013. 